\title{
Is Marine Conservation Science Becoming Irrelevant to Policy Makers?
}

\author{
E. C. M. Parsons ${ }^{1 *}$, D. A. DellaSala ${ }^{2}$ and A. J. Wright ${ }^{1}$ \\ ${ }^{1}$ Department of Environmental Science and Policy, George Mason University, Fairfax, VA, USA, ${ }^{2}$ Geos Institute, \\ Ashland, OR, USA
}

Keywords: marine conservation, policy making, US congress, climate change, scientific whaling, endangered species act

\section{OPEN ACCESS}

Edited by:

Romuald Lipcius,

Virginia Institute of Marine Science,

College of William \& Mary, USA

Reviewed by:

Leslie Cornick,

Alaska Pacific University, USA

${ }^{*}$ Correspondence:

E. C. M. Parsons ecm-parsons@earthlink.net

Specialty section:

This article was submitted to Marine Conservation and Sustainability,

a section of the journal

Frontiers in Marine Science

Received: 09 September 2015 Accepted: 09 November 2015 Published: 27 November 2015

Citation:

Parsons ECM, DellaSala DA and Wright AJ (2015) Is Marine Conservation Science Becoming

Irrelevant to Policy Makers?

Front. Mar. Sci. 2:102.

doi: 10.3389/fmars.2015.00102
The use of science in policy-making has declined dramatically around the world. One of the most obvious examples of scientific neglect is the refusal of many U.S. politicians to accept anthropogenic climate change despite overwhelming scientific evidence to the contrary. While over $97 \%$ of scientists recognize the global threat posed by human climate forcing (Oreskes, 2004a; Doran and Zimmerman, 2009; Anderegg et al., 2010; Cook et al., 2013), 72\% of Republican Senators in 2014 were climate change deniers (Schulman, 2015). Senator Jim Inhofe, the chair of the US Congressional Environment and Public Works Committee is an infamous climate change denier who even published a book called "The Greatest Hoax: How the Global Warming Conspiracy Threatens Your Future" (Inhofe, 2012). Such science contrarians among politicians are not uncommon, but when directly confronted on the issue two notable climate change deniers completely sidestepped it, stating "I'm not a scientist" (Senator Mitch McConnell) and "I'm not qualified to debate the science over climate change" (past House Speaker John A. Boehner; Davenport, 2014). Another problem is the treatment of information provided by the best available science as "just another opinion" at the table, to be negotiated and compromised (e.g., Schneider, 2009; Wright, 2010).

Here, we seek to shine a global spotlight on the alarming disregard for science in policy decisions affecting biodiversity conservation, mainly of relevance to marine scientists. We also suggest ways for scientific societies to speak out professionally in defense of conservation science.

\section{SCIENCE, NOT ACTION}

It is common for policy-makers to highlight a lack of scientific data and call for additional research. Superficially beneficial, the reason for this call for information is all too often not because more evidence is actually required, but because action can be postponed "pending further data," or to obfuscate likely problems with data on less likely candidates that "need further study" (Oreskes, 2004b). Unfortunately, grant-limited scientists can often be easily distracted by the promise of additional funding. This practice is, however, the antithesis of the precautionary principle, enshrined in the 1992 Rio Declaration (Principle 15), which states "Where there are threats of serious or irreversible damage, lack of full scientific certainty shall not be used as a reason for postponing cost-effective measures to prevent environmental degradation."

For instance, Mexican officials refused to implement conservation measures for the vaquita (or Gulf of California harbor porpoise, Phocoena sinus) following the publication of "Saving the vaquita: immediate action, not more data" in 2007 (Jaramillo-Legorreta et al., 2007), until more data were collected and the population decline "confirmed." It has taken an additional survey in 2008, acoustic data collection since from that time and the reduction of the species to $<100$ individuals (Comité Internacional Para La Recuperación De La Vaquita (CIRVA), 
2014) to finally convince the Mexican government to take muchneeded actions (which were only actually implemented after even further delays).

\section{SUPPRESSION OF SCIENCE IS A GLOBAL PHENOMENON}

In Canada, the Federal Government receives petitions for listing under the Species At Risk Act from an independent science advisory body-the Committee on the Status of Endangered Wildlife in Canada-yet seldom follows scientific recommendations. One example was the science-based recommendation to list the polar bear (Ursus maritimus), which has been repeatedly denied by the Canadian Government (Plotkin and Wallace, 2007). Canada's obstruction of scientifically-supported polar bear protections also extended to the actions of the Convention on the International Trade in Endangered Species (CITES; Parsons and Cornick, 2011, 2013). Another concern is that the Canadian Government has recently employed a policy prohibiting government scientists directly engaging with anyone about their work. Over the same period, Canadian science has been heavily defunded (Turk, 2015).

The U.S. also went through eight years of unprecedented political interference and compromise of scientific integrity under the Bush Administration, especially with regard to the Endangered Species and Clean Air Acts. For example, Greenwald et al. (2012) noted that scientific peer-review recommendations to increase habitat protections for endangered species were much more likely to be ignored than recommendations for reductions. In one case $75 \%$ of peer-reviewers recommended increasing habitat protection for the Cape Sable seaside sparrow (Ammodramus maritimus mirabilis) and were ignored. The situation looked to be improving when, in March 2009, the Obama White House issued a memorandum to reverse or revisit many well-documented obstructions of scientific integrity involving federal recovery plans and critical habitat determinations (Union of Concerned Scientists, 2004). However, monitoring by the Union of Concerned Scientists (Grifo, 2013) showed insufficient progress since the memorandum, reporting that only 6 of 22 federal agencies had put into place adequate scientific integrity policies. Furthermore, the majority of scientists from the U.S. Fish and Wildlife Service and the National Oceanic and Atmospheric Administration currently believe that consideration of political interests is too high at their agency (Union of Concerned Scientists, 2015).

In Europe, the situation is not substantially better (Goldstein, 2010). For example, scientific advice was actively undermined when the UK implemented the highly controversial program to cull badgers (Meles meles), supposedly to prevent the spread of tuberculosis to cattle (Brumfiel, 2012). In particular, relevant ecological studies were also downplayed (e.g., Donnelly et al., 2006). Returning to marine examples, British Ministers agreed to a $5 \%$ increase in total allowable fish catches in the North Sea, despite recommendations from Governmental fisheries scientists for a $20 \%$ decrease in catch quotas due to overfishing and stock depletion (Everett, 2015).
One high profile example from Asia is "scientific whaling," which involves lethal sampling for research purposes, as allowed under clause (Article 8) in the International Convention on the Regulation of Whaling (ICRW). The Japanese Government ascertained that their North Pacific (JARPN) and Antarctic (JARPA) lethal "research" programs provide important scientific data. However, these programs have been heavily criticized by scientists, including a majority of the scientific committee of the International Whaling Commission (IWC), who administer the ICRW (Clapham et al., 2003). They argue that the scientific rational for, and the rigor of, the programs is poor, and that they merely offer a means to conduct whaling under the guise of research during the current moratorium on commercial takes. Support offered includes the: lack of testable hypotheses; inappropriate use of ecosystem models; selective or inappropriate use of data and/or methods for estimating abundance; inappropriate geographic spread of sampling; and lack of consideration of population status (Clapham et al., 2003). Proponents of scientific whaling argue the validity and value of the program and that opposition results from differing opinions (and biases) about this value (e.g., Aron et al., 2002). But Clapham et al. (2003) counter "...just how bad does science have to be before [it] ceases to be a matter of opinion” (p. 212). Support for this opinion was provided by the 2014 ruling of the International Court of Justice that Japan's Antarctic JARPA program was not scientific research and thus effectively illegal ${ }^{1}$. Fortunately, science-based decision-making also found some support at the IWC when resolution (IWC/65/14 Rev 1$)^{2}$ was passed which requires, in part, that future takes for scientific purposes are to be assessed on their scientific (and conservation) merit.

\section{SHIFT HAPPENS}

Conservation scientists have been increasingly seen as irrelevant in the political arena since their prominence in the early 1970's. Many NGOs have been replacing their scientists with enthusiastic activists without extensive scientific background, presumably because they view them as more effective in modern conservation. Yet recognition of the need for conservation policy to be based on scientific evidence remains (Pullin and Knight, 2012; Adams and Sandbrook, 2013; Rose, 2015; Walsh et al., 2015).

Meanwhile, scientists debate whether they should advocate for science (Lackey, 2007; Noss, 2007; Chan, 2008; Nelson and Vucetich, 2009; Parsons, 2013; Scheufele, 2014; Wright, 2015), or remain policy-neutral and firmly in the "ivory tower." This issue is complicated by the lack of consensus among scientists on the exact definition of "advocacy." For example, Parsons (2013) argues that advocacy for conservation scientists could often be viewed as ensuring that the best science is in the right hands, at the right time and in the right format, whilst Wright (2015) argues that this simple action probably falls more under the term outreach, rather than advocacy. Many scientists even consider

\footnotetext{
${ }^{1}$ The judgement can be found at: http://www.icj-cij.org/docket/files/148/ 18136.pdf. A summary press release on the judgment being found at: www.icj-cij.org/docket/files/148/18162.pdf

${ }^{2}$ Downloadable from: https://archive.iwc.int/pages/view.php?ref=3452
} 
correcting media errors or simply sending their papers to policy makers as advocacy. This confusion, along with the disregard many scientists hold for "advocates," means that many scientists leave policy-makers when they ignore scientific information aside during decision-making processes.

Disregard for scientific information in policy decisions affecting biodiversity and natural resources may dissuade attempts to reach out to the highest levels (e.g., the increasingly anti-science U.S. Congress; Merchant, 2015). Fortunately, scientists may find a warmer welcome from local policy makers or managers. However, the global nature of climate change policy and endangered species conservation mean that marine scientists need to re-double their science-policy engagement at all levels, despite ongoing political tensions over scientific integrity.

Such efforts require an investment in time, and frequently also money, on the part of a given individual. Marine scientists that choose to enter the policy arena are seldom recognized or rewarded for speaking out. Some societies and NGOs provide awards for service to conservation; however, such acknowledgments are few and far between. One way for scientists to get more recognition for this work would be to change the way journals measure impact factor. This would involve recognizing scientific papers not only for their citation frequency but also if they have had any measurable impact on policy or management (e.g., Thornhill, 2013, 2014).

\section{MARINE CONSERVATION SCIENCE-A NEW HOPE?}

More immediately, institutions that house marine scientists need to acknowledge the importance of science-policy engagement, both as an academic pursuit and the responsibility of an engaged citizenship. Members will need these institutions to dedicate financial resources, provide outreach training for both young and seasoned professionals, and facilitate wider scientific discourse. The latter point will require elegantly simple representation of complex scientific constructs for decision makers and the public and emphasizing the relevance and importance of science in the policy arena.

With this in mind, we suggest several actions that marine conservation institutions could undertake or facilitate:

- Initiate training courses on policy processes and developing communication skills.

- Hold specific symposia and workshops at relevant academic meetings on scientific engagement with policy processes. One obvious host is the International Marine Conservation Congress, but other possible meetings include the International Congress for Conservation Biology, the Society for Marine Mammalogy Biennial Conference, as well as the conferences of the American Fisheries Society and others.

- Create or support journals of an applied orientation that would facilitate discussions about the interpretation of conservation science in the real-world.

- Invest in resources and people power to increase the media presence of marine conservation, especially on social media, as well as build relationships with science journalists. This includes funding for policy programs at scientific societies.

- Fund, support and promote fellowships schemes like the Leopold Leadership Program (https://leopoldleadership. stanford.edu), the David H. Smith Conservation Research Fellowship (http://conbio.org/mini-sites/smith-fellows) and the Liber Ero Conservation Fellowship (http://liberero.ca/). These programs provide valuable practical skills and support for researchers wanting to advocate for their science.

- Partner with science-based NGOs that liaise with relevant local policy makers and agencies.

- Connect marine NGOs that need independent scientific expertise with member scientists and vice versa.

- Increase broader marine science representation at key treaty meetings where science plays a part (e.g., the Convention on the International Trade in Endangered Species, the International Whaling Commission, the Convention on Migratory Species, and others).

- Conduct scientist "fly-ins" to visit with decision-makers (e.g., in Washington D.C.) in policy fora and science-policy briefings.

While a global problem, the dismissal use of science in U.S. policy-making is in many ways most perplexing as the country is one of the largest funders of science and conservation globally (e.g., $\$ 1.7$ billion spent on endangered species conservation in 2012 alone; Platt, 2013). Moreover, the US Constitution obligates Congress "To promote the Progress of Science." The current disregard of science in the US would have almost certainly horrified the scientiststatesmen among the Founding Fathers, such as Thomas Jefferson and Benjamin Franklin (who was also a Fellow of the Royal Society). Yet scientific disregard and censorship by policy-makers continues. Thus, unless willing to accept Pope Francis as the most outspoken advocate for science in policy, conservation institutions need to be more proactive rather than reactive in order to promote the importance of evidence in robust global conservation policy making, or risk become even more sidelined and irrelevant in the conservation arena.

Epilogue: While this manuscript was in review, a new government was elected in Canada. While there are likely many reasons for this, science had been heavily debated in the campaign and eventual winner, Liberal leader Justin Trudeau, had promised to reverse the cuts made to ocean science and monitoring programs by the previous Government (Halpern, 2015). However, the situation in Canada deteriorated so badly that scientists resorted to demonstrating on the street of Ottawa before embarking on a systematic effort to raise awareness. We strongly urge the scientific community not to wait so long elsewhere before engaging.

\section{ACKNOWLEDGMENTS}

The authors wish to thank George Mason University Library for funding open access charges for ECMP and AJW. 


\section{REFERENCES}

Adams, W. M., and Sandbrook, C. (2013). Conservation, evidence and policy. Oryx 47, 329-335. doi: 10.1017/S0030605312001470

Anderegg, W. R. L., Prall, J. W., Harold, J., and Schneider, S. H. (2010). Expert credibility in climate change. Proc. Natl. Acad. Sci. U.S.A. 107, 12107-12109. doi: $10.1073 /$ pnas. 1003187107

Aron, W., Burke, W., and Freeman, M. (2002). Scientists versus whaling: science, advocacy, and errors of judgment. BioScience 52, 1137-1140. doi: 10.1641/00063568(2002)052[1137:SVWSAA]2.0.CO;2

Brumfiel, G. (2012). Badger battle erupts in England. Nature 490, 317-318. doi: $10.1038 / 490317 a$

Chan, K. M. (2008). Value and advocacy in conservation biology: crisis discipline or discipline in crisis? Conserv. Biol. 22, 1-3. doi: 10.1111/j.15231739.2007.00869.x

Clapham, P. J., Berggren, P., Childerhouse, S., Friday, N. A., Kasuya, T., Kell, L., et al. (2003). Whaling as science. BioScience 53, 210-212. doi: 10.1641/00063568(2003)053[0210:WAS]2.0.CO;2

Comité Internacional Para La Recuperación De La Vaquita(CIRVA). (2014). "Report of the Fifth Meeting of the 'Comité Internacional Para La Recuperación De La Vaquita' (CIRVA-5)," Held at the Hotel Coral y Marina (Ensenada, B.C.). Available online at: http://assets.worldwildlife.org/publications/713/files/ original/2014_Vaquita_Report_Fifth_Meeting_of_CIRVA.pdf?1408479198

Cook, J., Nuccitelli, D., Green, S. A., Richardson, M., Winkler, B., Painting, R., et al. (2013). Quantifying the consensus on anthropogenic global warming in the scientific literature. Environ. Res. Lett. 8:024024. doi: 10.1088/1748$9326 / 8 / 2 / 024024$

Davenport, C. (2014). Why Republicans keep telling everyone they're not scientists. New York Times. Available online at: http://www.nytimes.com/ 2014/10/31/us/why-republicans-keep-telling-everyone-theyre-not-scientists. html?_r=0 (Accessed October 30, 2014).

Donnelly, C. A., Woodroffe, R., Cox, D. R., Bourne, F. J., Cheeseman, C. L., CliftonHadley, R. S., et al. (2006). Positive and negative effects of widespread badger culling on tuberculosis in cattle. Nature 439, 843-846. doi: 10.1038/nature04454

Doran, P., and Zimmerman, M. (2009). Examining the scientific consensus on climate change. EOS Trans. Am. Geophys. Union 90, 22-23. doi: $10.1029 / 2009$ EO030002

Everett, S. (2015). Carry on fishing. Br. Wildl. 26, 220-221.

Goldstein, S. (2010). Parliament needs members who are scientifically literate. Nature 463, 876-877. doi: 10.1038/463876c

Greenwald, D. N., Suckling, K. F., and Pimm, S. L. (2012). Critical habitat and the role of peer review in Government decisions. BioScience 62, 686-690. doi: 10.1525/bio.2012.62.7.11

Grifo, F. T. (2013). Federal Agency Scientific Integrity Policies: A Comparative Analysis. Union of Concerned Scientists. Available online at: http://www. ucsusa.org/sites/default/files/legacy/assets/documents/scientific_integrity/SIpolicies-comparative-analysis.pdf

Halpern, M. (2015). How Science Helped to Swing the Canadian Election. Available online at: http://www.theguardian.com/science/political-science/2015/oct/21/ how-science-helped-to-swing-the-canadian-election (Accessed 21 October, 2015)

Inhofe, J. M. (2012). The Greatest Hoax: How the Global Warming Conspiracy Threatens your Future. Washington, DC: WND Books.

Jaramillo-Legorreta, A., Rojas-Bracho, L., Brownell, R. L., Read, A. J., Reeves, R. R., Ralls, K., et al. (2007). Saving the vaquita: immediate action, not more data. Conserv. Biol. 21, 1653-1655. doi: 10.1111/j.1523-1739.2007.00825.x

Lackey, R. T. (2007). Science, scientists, and policy advocacy. Conserv. Biol. 21, 12-17. doi: 10.1111/j.1523-1739.2006.00639.x

Nelson, M. P., and Vucetich, J. A. (2009). On advocacy by environmental scientists: what, whether, why, and how. Conserv. Biol. 23, 1091-1101. doi: 10.1111/j.15231739.2009.01250.x

Noss, R. (2007). Values are a good thing in conservation biology. Conserv. Biol. 21, 18-20. doi: 10.1111/j.1523-1739.2006.00637.x

Merchant, B. (2015). The Most Anti-science Congress in Recent History is Now in Session. Available online at: http://motherboard.vice.com $/ \mathrm{read} / \mathrm{meet}$-themost-anti-science-congress-in-modern-history\# (Accessed 15 January, 2015).
Oreskes, N. (2004a). The scientific consensus on climate change. Science 306, 1686. doi: $10.1126 /$ science. 1103618

Oreskes, N. (2004b). Science and public policy: what's proof got to do with it? Environ. Sci. Policy 7, 69-383. doi: 10.1016/j.envsci.2004.06.002

Parsons, E. C. M. (2013). So you want to be a Jedi? Advice for conservation researchers wanting to advocate for their findings. J. Environ. Stud. Sci. 3, 340-342. doi: 10.1007/s13412-013-0133-0

Parsons, E. C. M., and Cornick, L. (2011). Sweeping scientific data under a polar bear skin rug: the IUCN and the proposed listing of polar bears under CITES Appendix I. Mar. Policy 35, 729-731. doi: 10.1016/j.marpol.2011. 02.001

Parsons, E. C. M., and Cornick, L. (2013). Politics, people and polar bears. Mar. Policy 42, 178-179. doi: 10.1016/j.marpol.2013.02.003

Platt, J. R. (2013). How Much did the U.S. Spend on the Endangered Species Act in 2012? Available online at: http://blogs.scientificamerican.com/extinctioncountdown/2013/11/01/endangered-species-act-2012/

Plotkin, R., and Wallace, S. S. (2007). Left of the List. Vancouver: David Suzuki Foundation. Available online at: http://www.davidsuzuki.org/publications/ downloads/2007/DSF-LOTL-final2.pdf

Pullin, A. S., and Knight, T. M. (2012). Science informing policy-a health warning for the environment. Environ. Evid. 1:15. doi: 10.1186/2047-2382-1-15

Rose, C. (2015). The case for policy-relevant conservation science. Conserv. Biol. 29, 748-754. doi: 10.1111/cobi.12444

Scheufele, D. A. (2014). Science communication as political communication. Proc. Natl. Acad. Sci. U.S.A. 111, 13585-13592. doi: 10.1073/pnas.1317516111

Schneider, S. H. (2009). Science as a Contact Sport: Inside the Battle to Save Earth's Climate. Washington, D.C.: National Geographic Society.

Schulman, J. (2015). 72 Percent of Republican Senators are Climate Deniers. Available online at: http://m.motherjones.com/blue-marble/2015/01/ republican-climate-denial-caucus (Accessed 10 January, 2015).

Thornhill, J. (2013). "Can new metrics help us bridge the gap? A case study in the measurement of scientific literature's impact on decision making," in Paper Presented at the International Congress for Conservation Biology (Baltimore, MD).

Thornhill, J. (2014). "Can researchers climb the career ladder while bridging the gap? Building an understanding of "dual impact" research," in Paper presented at the North America Congress for Conservation Biology (Missoula, MT).

Union of Concerned Scientists (2004). Scientific Integrity in Policy Making. Union of Concerned Scientists. Available online at: http://www.ucsusa.org/our-work/ center-science-and-democracy/promoting-scientific-integrity/scientificintegrity-in.html\#.VMGTdWTF9Vg

Union of Concerned Scientists (2015). Progress and Problems. Government Scientists Report on Scientific Integrity at Four Agencies. Union of Concerned Scientists. Available online at: http://www.ucsusa.org/sites/default/files/attach/ 2015/09/ucs-progress-and-problems-2015.pdf

Turk, J. L. (2015). A chance to get science right. Science 350, 139. doi: $10.1126 /$ science.aad5667

Walsh, J. C., Dicks, L. V., and Sutherland, W. J. (2015). The effect of scientific evidence on conservation practitioners' management decisions. Conserv. Biol. 29, 88-98. doi: 10.1111/cobi.12370

Wright, A. J. (2010). Scientific talk on climate change. Available online at: http://www.politico.com/news/stories/1110/45651.html (Accessed November 29, 2010).

Wright, A. J. (2015). Defending the ivory tower against the end of the world. J. Environ. Stud. Sci. 5, 66-69. doi: 10.1007/s13412-015-0227-y

Conflict of Interest Statement: The authors declare that the research was conducted in the absence of any commercial or financial relationships that could be construed as a potential conflict of interest.

Copyright (C) 2015 Parsons, DellaSala and Wright. This is an open-access article distributed under the terms of the Creative Commons Attribution License (CC BY). The use, distribution or reproduction in other forums is permitted, provided the original author(s) or licensor are credited and that the original publication in this journal is cited, in accordance with accepted academic practice. No use, distribution or reproduction is permitted which does not comply with these terms. 